\title{
Floral and reproductive biology of Alpinia purpurata (Vieill.) K. Schum. (Zingiberaceae): An important tropical ornamental plant
}

\section{Biología floral y reproductiva de Alpinia purpurata (Vieill.) K. Schum. (Zingiberaceae): Una importante planta ornamental tropical}
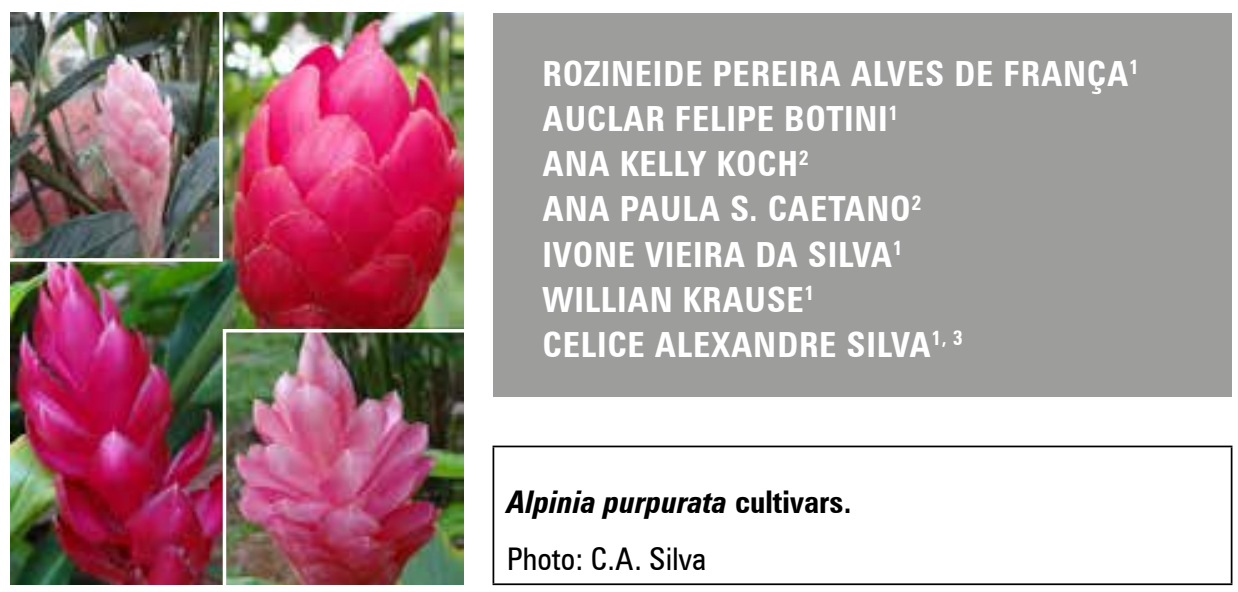

\begin{abstract}
Alpinia spp. play an important ecological role as a source of nectar in the understory of tropical and subtropical forests and many are common. The perennial species Alpinia purpurata (Vieill.) K. Schum. is native to the tropical rainforests of Asia and has been used as an ornamental cut plant because of its lush inflorescences and post-harvest durability. The internal and external morphology, floral biology, and reproductive system of four A. purpurata cultivars were investigated to contribute to studies on the genetic improvement of this species. The inflorescence of $A$. purpurata is terminal and globose, and has flowers protected by colorful and showy bracts. The white flowers are tubular and bisexual. The floral anthesis of these four cultivars lasted 9 to 12 hours, and the pollen viability was above $80 \%$ throughout the pre-flowering period in all evaluated cultivars. During anthesis, the stigma and anther crest were receptive because of the presence of stigmatic fluid. Fruiting was observed after hand cross-pollination, whereas no fruiting was recorded in the treatments with spontaneous self-pollination, hand self-pollination or geitonogamy. Natural pollination induced low fruiting, suggesting low pollinator availability in the studied area. The obligatory xenogamy of $A$. purpurata facilitates the development of new hybrids for the ornamental plant market.
\end{abstract}

Additional keywords: breeding system; floral structure; stigmatic fluid; stigmatic receptivity.

1 Universidade do Estado de Mato Grosso, Tangará da Serra (Brazil). ORCID França, R.P.A.: 0000-0001-8504-2928; ORCID Botini, A.F.: 0000-0003-4060-7942; ORCID Silva, I.V.: 0000-0003-0281-0608; ORCID Krause, W.: 0000-0002-5308-7715; ORCID Silva, C.A.: 0000-0001-7898-7931

2 Universidade Federal de Mato Grosso, Cuiabá (Brazil). ORCID Koch, A.K.: 0000-0002-9662-6459; ORCID Caetano, A.P.S.: 0000-0002-8256-0380

3 Corresponding author. celice@unemat.br 


\section{RESUMEN}

Alpinia spp. desempeñan un importante papel ecológico, como fuente de néctar, en el sotobosque de los bosques tropicales y subtropicales, donde muchas de estas especies son comunes. La especie perenne Alpinia purpurata (Vieill.) K. Schum. es nativa de las selvas tropicales de Asia y se ha utilizado como planta de corte ornamental debido a las exuberantes inflorescencias y la durabilidad posterior a la cosecha. Se investigó la morfología interna y externa, la biología floral y el sistema reproductivo de cuatro cultivares de A. purpurata, para apoyar los estudios de mejora genética de la especie. La inflorescencia de A. purpurata es terminal, globosa y tiene flores protegidas por brácteas coloridas y vistosas. Las flores blancas son tubulares bisexuales. La antesis floral de los cuatro cultivares duró entre 9 y 12 horas. La viabilidad del polen fue superior al $80 \%$ durante todo el período de pre-floración en todos los cultivares evaluados. Durante la antesis, el estigma y la cresta de la antera fueron receptivos. La fructificación de los cultivares se observó después de la polinización cruzada manual. No se registró fructificación en los tratamientos de autopolinización espontánea, autopolinización manual y geitonogamia. La polinización natural indujo baja fructificación, lo que sugiere una baja disponibilidad de polinizadores en el área estudiada. La xenogamia obligatoria de A. purpurata es un facilitador para el desarrollo de nuevos híbridos para el mercado de plantas ornamentales.

Palabras clave adicionales: sistema de reproducción; estructura floral; fluido estigmático; receptividad estigmática.

Received for publication: 14-03-2020 Accepted for publication: 11-06-2020
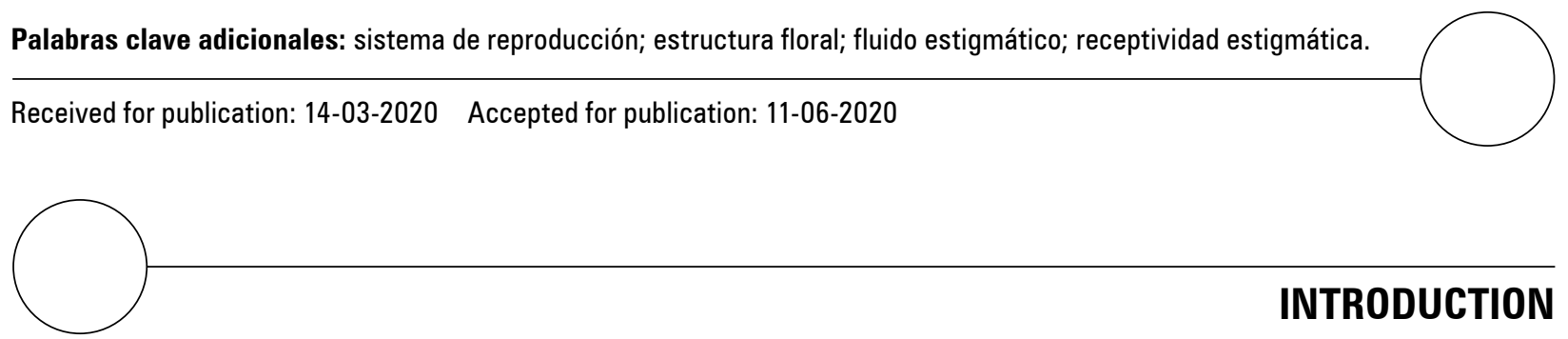

INTRODUCTION

Zingiberaceae Martinov is the largest family of the order Zingiberales, with 52 genera and about 1,600 species (WFO, 2019). The family has a pantropical distribution, with only one genus (Renealmia L.f.) distributed in the Neotropics and Africa, while four others (Alpinia Roxb., Curcuma L., Hedychium J. Koenig and Zingiber Mill.) were introduced into and naturalized in the Neotropics (Kress, 1990; Stevenson and Stevenson, 2004; Hamidou et al., 2012). In Brazil, the family is represented by eight genera, 32 species and one subspecies (BFG, 2015, JBRJ, 2020).

The floral morphology of the family invariably consists of bisexual and zygomorphic flowers with a normally tubular calyx, formed by two sepals, a corolla with three petals and two fused petaloid staminodes, forming an abaxial labellum, and a functional stamen with two thecae (Kirchoff, 1988; Endress, 1994). Additionally, more than 25 genera in this family have a crest at the anther apex, with broad variation in shape and size (Fan and Li, 2012; 2016).

The anther crest is a specialized anther appendage that extends up from the top of the anther to form a tail-like structure, with broad variation in shape and size between the different genera, and is widely characterized in the Zingiberaceae family. The function of the anther crest is to boost the male and female functions of plants, directing pollinators to an ideal position for removing and receiving pollen (Fan and Li, 2016).

The style is thin, and the anther fillet is inside a ventral groove between the thecae. The fusion of the lateral staminodes into a labellum, the presence of a pair of nectariferous glands at the style base, and cells containing essential or ethereal oils are autapomorphies in this family (Kress, 1990).

The peculiar floral morphology of the family Zingiberaceae may be related to a specialized floral system. Flexistyly is a sexual dimorphism consisting of two forms that differ in the temporal expression of sexual function and that involve the reciprocal movement of the stigmatic surface through a vertical axis during the flowering period, which combines reciprocal herkogamy and dichogamy and promotes outcrossing (Li et al., 2001; Cardoso et al., 2018). This strategy has been documented in 24 Zingiberaceae species, including those within the genus Alpinia (Kress et al., 2001).

Alpinia is the largest genus of the family Zingiberaceae, with 346 widely distributed species in tropical Asia (Smith, 1990; Kress et al., 2001). The following three species are frequently cultivated in Brazil: A. 
purpurata (Vieill.) K. Schum., A. vittata W. Bull, and A. zerumbet (Pers.) B.L. Burtt \& R.M. Sm. (JBRJ, 2020). Studies based on molecular data have suggested that this genus is highly polyphyletic (Kress et al., 2001), and most authors consider it to be taxonomically difficult and complex (Smith, 1990; Kress et al., 2001).

Apart from an important ecological role in the understory of tropical and subtropical forests, Alpinia species can be used as medicinal plants (e.g., A. officinarum Hance), as food (A. galanda (L.) Willd.) or for landscaping purposes (A. zerumbet), mainly as cut flowers, as is A. purpurata (Althaus-Ottmann et al., 2011), which has varied color bracts and great ornamental value for decorative purposes in gardens and landscapes because of the durability and exuberance of its inflorescences with year-round flowering.

Reproductive biological studies are essential for the cultivation, conservation, and genetic development of plants (Baskorowati et al., 2010). Knowledge on the reproductive barriers of Alpinia helps the development of research on this promising ornamental plant. The main goal of the present study was to examine the floral morphology and morphometry of four $A$. purpurata cultivars and to analyze their reproductive system, focusing on pollen and stigma viability.

\section{MATERIALS AND METHODS}

\section{Study location}

The active germplasm bank (BAG) of the Universidade do Estado de Mato Grosso in the municipality of Tangara da Serra, MT-Brazil (14'39 'S, 57² $25^{\circ}$ W; $321 \mathrm{~m}$ a.s.l.) was the study site for the four $A$. purpurata cultivars (Jungle King, Kimi, Pink Ginger and Red Ginger) planted in August, 2015. The regional climate is tropical, with a dry season from May to September and a rainy season from October to April, and an average annual rainfall of 1,830 mm (Dallacort et al., 2011). The soil was classified as Latossolo Vermelho Distroférrico, clayey, with a flat to slightly undulating topography (Embrapa, 2018).

\section{Floral morphology and morphometry}

The morphological characteristics were evaluated and illustrated with drawings of flowers during the anthesis period, detailing the external morphological characteristics of $A$. purpurata flowers. Photomicrographs were taken with a Leica DMLB photomicroscope equipped with a Zeiss Axio Cam digital camera.

The floral morphometry of the four A. purpurata cultivars (Jungle King, Kimi, Red Ginger and Pink Ginger) was analyzed in fresh flowers in anthesis $(\mathrm{N}=$ 25). A pachymeter was used to measure the flower length and width.

Statistical analyses were performed using Sisvar ${ }^{\circledR}$ (Ferreira, 2000). The means and standard deviation of the floral structures of the four A. purpurata cultivars were compared by the Tukey test.

\section{Floral biology}

Floral anthesis, pollen viability and stigmatic receptivity were observed in 40 flowers from 10 plants per cultivar at flowering peak, from March to May of 2016. During anthesis, the flowers were monitored from the beginning of opening until senescence, characterized by a loss of glossiness and darkening of the flower.

Pollen viability was determined in previously bagged flowers in anthesis. The flowers were evaluated every two hours, from 07:00 AM to 5:00 PM. At each sampling, five slides per cultivar were mounted. The pollen grains were stained with acetic carmine, and 200 units per slide were counted with an optical microscope (Kearns and Inouye, 1993). Grains with stained protoplasm were deemed viable, and those with a translucent and ruptured envelope were deemed unviable.

The stigmatic receptivity of the flowers used in the pollen viability tests was evaluated with two solutions: alpha naphthyl acetate, in which the reaction with esterase darkens the stigma if it is receptive, and hydrogen peroxide $\left(\mathrm{H}_{2} \mathrm{O}_{2}\right)$, which, through the presence of the enzyme peroxidase, indicates receptivity by forming air bubbles (Kearns and Inouye, 1993). In addition to the stigmatic region, the solutions were also used to test the receptivity of the anther crest located just above the stigma because the presence of stigmatic fluid in this structure facilitates the reception of pollen grains.

\section{Breeding system}

\section{Pollination treatments}

Preliminary observations confirmed the receptivity of the anther crest in the four A. purpurata cultivars. 
Therefore, controlled pollination was carried out with three methods: (1) simultaneously on the stigma and anther crest, (2) only on the stigma, and (3) only on the anther crest.

The flowers of all cultivars, previously protected with organza bags, were hand-pollinated between 07:00 and 09:00 AM. After pollination, the inflorescences were bagged again and monitored until flower senescence or fruit formation.

The previously bagged inflorescences and floral pedicels of the four $A$. purpurata cultivars were pollinated as follows: (1) spontaneous self-pollination, bagging inflorescences with intact flowers; (2) hand selfpollination of previously bagged inflorescences with the manual transfer of pollen to stigma on the same flower; (3) geitonogamous pollination of previously bagged inflorescences with pollen transfer between flowers on the same plant; (4) cross-pollination of inflorescences with pollen transfer between flowers from different cultivars; (5) natural pollination (control) of inflorescences exposed to pollinators and monitoring of fruit formation.

The criteria for the selection of cultivars for crosspollination were chosen with the ornamental plant market in mind, such as variations in the color of the bract and productivity among cultivars.

The low number of flowers in the Red Ginger and Pink Ginger cultivars was possibly due to investment in the aerial plant parts (bulblets) in the bract axils.

\section{Pollen tube growth}

The pollen tube growth was analyzed in the ventral region of the anther crest. The flowers were collected
$1 \mathrm{~d}$ (approximately $24 \mathrm{~h}$ ) after manual and natural pollination and fixed in FAA for approximately 36 h. For slide preparation, the flowers ( $N=25$ flowers per cultivar) were rinsed three times in distilled water and treated with sodium hydroxide $(8 \mathrm{~N} \mathrm{NaOH})$. The pistils were then mounted on slides and stained with $0.1 \%$ aniline blue solution at $0.1 \mathrm{~mol} / \mathrm{L} \mathrm{K}_{3} \mathrm{PO}_{3}$ (potassium phosphite). The pollen tube growth was observed with an Olympus BX 51 epifluorescence microscope.

\section{RESULTS AND DISCUSSION}

A. purpurata inflorescence is terminal, globose or spiciform, and the flowers are protected by colorful and conspicuous bracts (Fig. 1A, 2A). Five to seven flowers or vegetative propagules (bulblets) emerge from each bract. The flowers are tubular, bisexual, zygomorphic, and white (Fig. 1B-C, Fig. 2 A-B) and have a fused calyx, a tubular corolla with three petals fused with the curved distal lobes, one fertile stamen with a conspicuous anther grooved ventrally with the apex crest (Fig. 1D), and four external lateral staminodes, two on either side, forming a petaloid labellum (Fig. 1E). The stigma is exserted above the anther, flattened (claviform) and moist, with a ciliate margin (Fig. 1E). The upper part of the ovary has two epigynous nectaries surrounding the style base (Fig. 1F). The ovary is tricarpellary, trilocular and plurilovular. The fruit has a 3-valved dry or fleshy capsule, dehiscent from apex to base, containing numerous toothed seeds.

The morphometric calyx and corolla characteristics of the Red Ginger and Pink Ginger cultivars were similar, while the other cultivars differed significantly from each other in this regard (Tab. 1).

Table 1. Flower morphometry of four Alpinia purpurata cultivars.

\begin{tabular}{|l|c|c|c|c|}
\hline Cultivars & Jungle King & Kimi & Red Ginger & Pink Ginger \\
\hline Floral structure length $(\mathrm{cm})$ & $\bar{X} \pm$ SD & $\bar{X} \pm S D$ & $\bar{X} \pm$ SD & $\bar{X} \pm$ SD \\
\hline Calyx & $2.38 \pm 0.11 \mathrm{a}$ & $2.16 \pm 0.14 \mathrm{~b}$ & $1.65 \pm 0.06 \mathrm{c}$ & $1.88 \pm 0.08 \mathrm{c}$ \\
\hline Corolla & $4.68 \pm 0.15 \mathrm{a}$ & $4.30 \pm 0.16 \mathrm{~b}$ & $3.10 \pm 0.17 \mathrm{c}$ & $3.48 \pm 0.20 \mathrm{c}$ \\
\hline Lacinia of the corolla & $1.42 \pm 0.10 \mathrm{a}$ & $1.38 \pm 0.09 \mathrm{a}$ & $1.00 \pm 0.06 \mathrm{~b}$ & $1.16 \pm 0.04 \mathrm{~b}$ \\
\hline Labellum & $1.32 \pm 0.05 \mathrm{a}$ & $1.22 \pm 0.08 \mathrm{a}$ & $0.96 \pm 0.02 \mathrm{~b}$ & $1.04 \pm 0.07 \mathrm{~b}$ \\
\hline Stigma & $4.12 \pm 0.12 \mathrm{a}$ & $3.47 \pm 0.16 \mathrm{~b}$ & $2.53 \pm 0.20 \mathrm{c}$ & $2.93 \pm 0.20 \mathrm{~b}$ \\
\hline Anther + crest & $0.97 \pm 0.02 \mathrm{a}$ & $0.88 \pm 0.02 \mathrm{~b}$ & $0.68 \pm 0.03 \mathrm{c}$ & $0.75 \pm 0.02 \mathrm{~d}$ \\
\hline Ovary & $0.60 \pm 0.04 \mathrm{a}$ & $0.65 \pm 0.06 \mathrm{a}$ & $0.57 \pm 0.09 \mathrm{a}$ & $0.58 \pm 0.02 \mathrm{a}$ \\
\hline
\end{tabular}

Means followed by the same letter in a row do not differ from each other according to the Tukey test at $5 \%$ probability; $n=25$ flowers. 


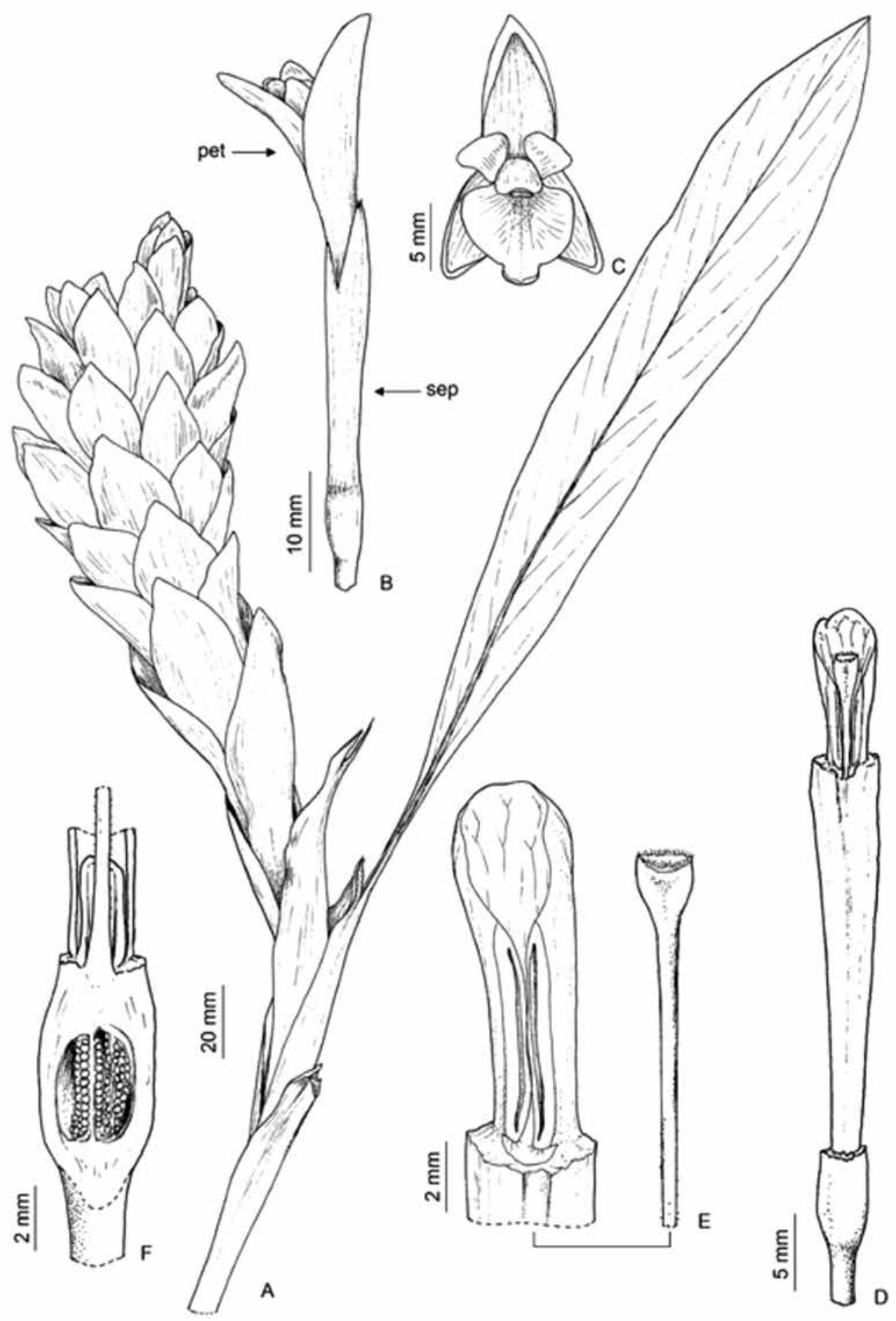

Figure 1. Terminal inflorescence of $A$. purpurata; A) stem apex with inflorescence; B) side view of the flower; C) front view of the flower; D) detail of the tubular corolla; E) detail of stigma and anther; F) inferior ovary with nectariferous glands at the fillet base. Illustration: R. Pinto. 
Table 1 shows the comparisons between the lengths of the floral structures. The length and labellum of the corolla lobes were proportional to the calyx length and corolla of the Jungle King and Kimi cultivars. The anther length and crest differed statistically between the cultivars and were related to corolla length. The ovary length did not differ significantly between the cultivars.
The different flower sizes observed in the four $A$. purpurata cultivars may have been the result of environmental differences, such as temperature and relative humidity, as recorded for other Alpinia species (Takano et al., 2013).

As observed for $A$. purpurata, there are many other plants in which all or some flowers of an inflorescence

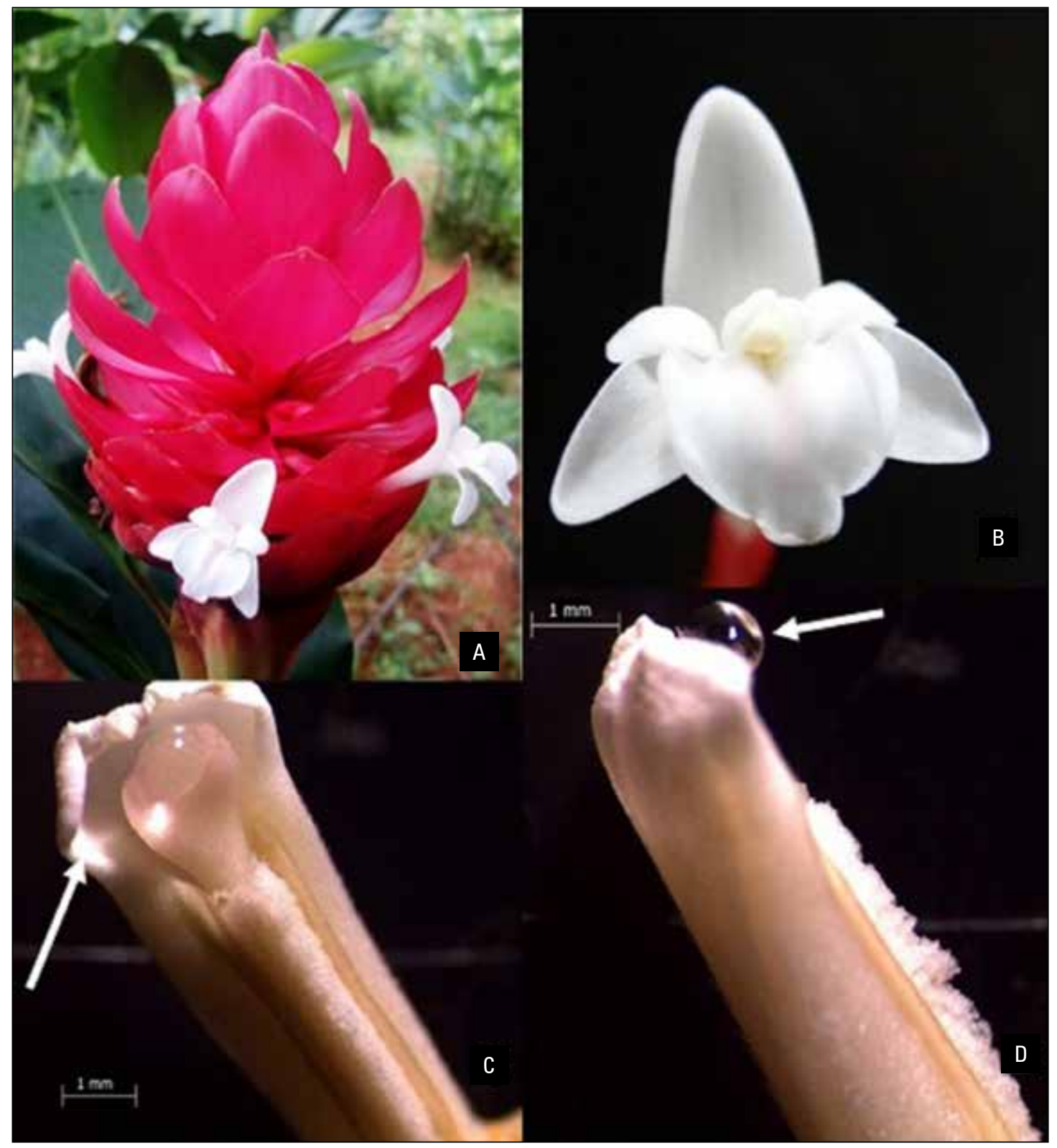

Figure 2. External morphology of Alpinia purpurata. A) Inflorescence with presence of flowers in the bracts; B) front view of flower; C) anther crest (arrow) and dehiscent anthers; D) side view of the anther crest with exudate release (arrow) at the stigma. 
are converted into asexual bulbs: Polygonum viviparum L. (Polygonaceae) (Diggle, 1997), Globba spp. (Zingiberaceae) (Box and Rudall, 2006), and Calathea marantifolia Standl. (Marantaceae) (Matlaga and Horvitz, 2009). According to Box and Rudall (2006), the production of bulblets allows herbaceous plants to grow vigorously and ensures fast establishment.

The anthesis period, characterized by the opening of the corolla lacinia in the four $A$. purpurata cultivars lasted 9 to $12 \mathrm{~h}$. Anthesis in the Jungle King, Red Ginger, and Pink Ginger cultivars started at 06:00 AM, and, in the Kimi cultivar, it started at about 09:00 AM. Anthesis ended between 05:00 and 06:00 PM on the same day. At the beginning of anthesis, the stigma was positioned above the anther, which was dehiscent. Unfertilized flowers were not abscised during the evaluation period. The ovary development of the fertilized flowers began about $4 \mathrm{~d}$ after pollination. The bracts remained attached to the inflorescence throughout fruit maturation. Style movements, such as "anaflexistylous" and "cataflexistylous" phenotypes, were not observed.

The stigmatic fluid was continuously secreted during flowering, forming a drop on the stigma, which could reach and cover the anther crest (Fig. 2C-D).
In Roscoea debilis (Zingiberaceae), the stigmatic fluid aids germination of pollen grains and pollen tube elongation in the styles (Fan and Li, 2012).

The receptivity of the stigma and anther crest was confirmed by the response to the alpha-naphthyl dye and the $\mathrm{H}_{2} \mathrm{O}_{2}$ solution (Fig. 3A-B). A pollen viability of more than $86 \%$ was observed in all cultivars during the evaluation period. The viability peak was between 07:00 and 11:00 AM (Tab. 2). Although the A. purpurata stigma was receptive when viable pollen was released, the stigma position above the anther hampers selfing in this species. The floral herkogamy prevented pollination within a flower but not between plants of the same cultivar.

The fruiting percentage in the cross-pollination treatments ranged from 60 to $83 \%$ between the cultivars (Tab. 3). The number of seeds/fruit with manual cross-pollination was 22\% lower for the Kimi cultivar than for the other cultivars (Tab. 3).

No full pollen tube growth in the anther crest tissue was recorded in any of the hand-pollinated treatments (Fig. 3C), and no fruiting was recorded after a manual pollen transfer in the anther crest region, indicating that this structure must act only in the

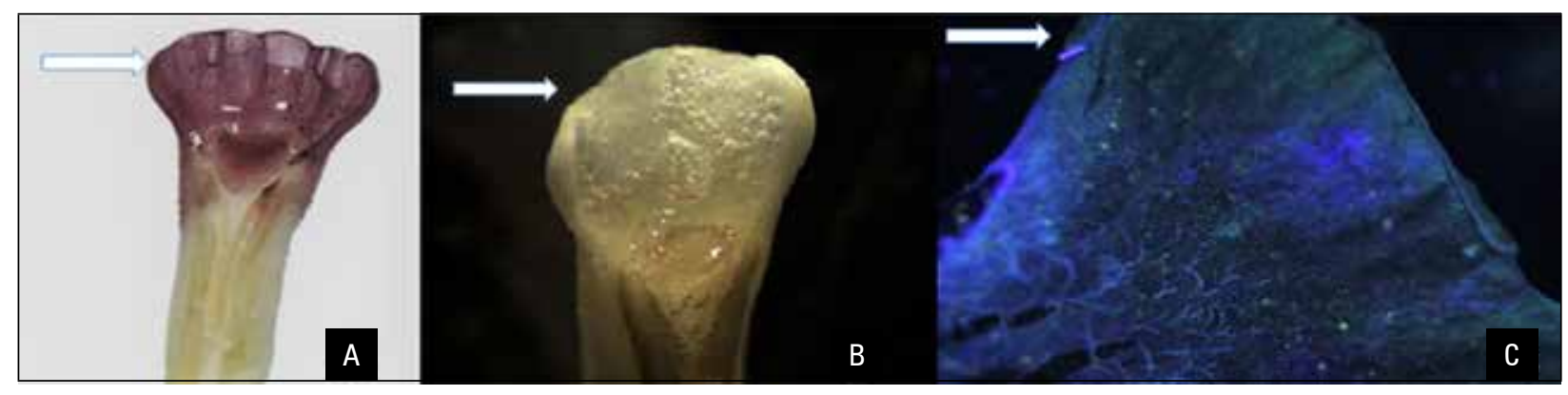

Figure 3. Receptor reaction in the anther crest and stigma of Alpinia purpurata (arrow). A) Receptivity using alpha naphthyl dye; B) receptivity using hydrogen peroxide; C) pollination in the anther crest underepifluorescence after $36 \mathrm{~h}$.

Table 2. Pollen viability (\%) of four Alpinia purpurata cultivars.

\begin{tabular}{|l|c|c|c|c|c|c|}
\hline Time of day/ & $7: 00$ & $9: 00$ & $11: 00$ & $13: 00$ & $15: 00$ & $17: 00$ \\
\hline Cultivars & $\bar{X} \pm$ SD & $\bar{X} \pm$ SD & $\bar{X} \pm S D$ & $\bar{X} \pm S D$ & $\bar{X} \pm S D$ & $\bar{X} \pm S D$ \\
\hline Jungle King & $94.5 \pm 2.6$ & $94.1 \pm 3.8$ & $94.5 \pm 2.1$ & $93.8 \pm 2.8$ & $89.7 \pm 3.5$ & $87.9 \pm 6.8$ \\
\hline Kimi & - & $95.1 \pm 1.7$ & $94.9 \pm 1.4$ & $95 \pm 1.4$ & $89.3 \pm 6.5$ & $87.8 \pm 6.5$ \\
\hline Red Ginger & $94.9 \pm 3.6$ & $95.3 \pm 1.3$ & $94.9 \pm 2.9$ & $90 \pm 4.1$ & $88.3 \pm 4.7$ & $86.6 \pm 6.1$ \\
\hline Pink Ginger & $93.6 \pm 2.1$ & $93.4 \pm 3.2$ & $93.8 \pm 2.0$ & $93.1 \pm 2.8$ & $89.9 \pm 4.0$ & $88.1 \pm 4.8$ \\
\hline
\end{tabular}

$n=25$ flowers. 
reception of pollen grains that germinate and emit pollen tubes that grow to the stigma through the stigmatic fluid. The simultaneous pollen transfer to the stigma and anther crest regions in the manual cross-pollination treatments caused a 45 and 52\% increase in seeds/fruit in the cross for the Kimi and Jungle King cultivars, respectively, as compared to manual cross-pollination only performed on the stigma (Tab. 3).

The treatments with spontaneous self-pollination, hand self-pollination and geitonogamy did not induce fruiting, indicating obligate xenogamy. Therefore, $A$. purpurata is an allogamous and self-incompatible species (Tab. 3).

The mating system of $A$. purpurata cultivars is exclusively xenogamous. The obligate xenogamy facilitates the breeding of new hybrids for the ornamental plant market (Luc-Cayol and Fereol, 1997). Flexistyly has been observed to promote outcrossing by avoiding self-pollination (Li et al., 2001). The absence of flexistyly in A. purpurata may be a result of the effectiveness of self-incompatible and herkogamy at preventing autogamy, with no need for another mechanism to promote cross-pollination. Self-compatibility with pollinator dependence has been reported in flexistylic Alpinia species (Li et al., 2002; Zhang et al., 2003; Krieck et al., 2008).

The lower number of fruits with the natural pollination than with the artificial pollination suggested that there was a limited presence of effective A. purpurata pollinators in the study area.

In the A. purpurata, although hand pollination of the anther crest did not induce fruit formation, this structure above the stigma, together with the stigma,

Table 3. Reproductive system of four Alpinia purpurata cultivars.

\begin{tabular}{|c|c|c|c|c|}
\hline \multicolumn{5}{|c|}{ Pollination on stigma + anther crest } \\
\hline Treatments & Cultivars & No. of flowers & $\begin{array}{l}\text { Fruiting percentage } \\
(\%)\end{array}$ & $\begin{array}{c}\text { No. of seed/fruit } \\
\bar{X} \pm S D\end{array}$ \\
\hline \multirow{4}{*}{ Cross pollination } & Kimi $^{1} \times$ Jungle King ${ }^{2}$ & 25 & 60.0 & $200.4 \pm 57.1$ \\
\hline & Jungle King ${ }^{1}$ x Kimi ${ }^{2}$ & 25 & 76.0 & $203.4 \pm 62.2$ \\
\hline & Red Ginger ${ }^{1}$ x Pink Ginger ${ }^{2}$ & 8 & 87.5 & $166.0 \pm 54.6$ \\
\hline & Jungle King ${ }^{1}$ x Pink Ginger ${ }^{2}$ & 6 & 83.0 & $158.6 \pm 51.3$ \\
\hline \multicolumn{5}{|c|}{ Pollination on anther crest } \\
\hline \multirow{2}{*}{ Cross pollination } & Kimi $^{1} \times$ Jungle King ${ }^{2}$ & 25 & 0.0 & 0.0 \\
\hline & Jungle King ${ }^{1}$ x Kimi ${ }^{2}$ & 25 & 0.0 & 0.0 \\
\hline \multicolumn{5}{|c|}{ Pollination on stigma } \\
\hline \multirow{2}{*}{ Cross pollination } & Jungle King ${ }^{1} \times$ Kimi $^{2}$ & 25 & 80.0 & $105.5 \pm 4.8$ \\
\hline & Kimi $^{1} \times$ Jungle King ${ }^{2}$ & 25 & 24.0 & $93.5 \pm 20.9$ \\
\hline \multirow{2}{*}{ Geitonogamy } & Jungle King & 25 & 0.0 & 0.0 \\
\hline & Kimi & 25 & 0.0 & 0.0 \\
\hline \multirow{2}{*}{ Spontaneous selfing } & Jungle King & 25 & 0.0 & 0.0 \\
\hline & Kimi & 25 & 0.0 & 0.0 \\
\hline \multirow{2}{*}{ Hand selfing } & Jungle King & 25 & 0.0 & 0.0 \\
\hline & Kimi & 25 & 0.0 & 0.0 \\
\hline \multirow{4}{*}{ Natural pollination } & Jungle King & $=288^{*}$ & 10.0 & $178.9 \pm 34.0$ \\
\hline & Kimi & $=280^{*}$ & 0.0 & 0.0 \\
\hline & Pink Ginger & - & - & 0.0 \\
\hline & Red Ginger & - & - & 0.0 \\
\hline
\end{tabular}

${ }^{1}$ In the crosspollinated treatments, pollen receptor; ${ }^{2} \mathrm{X}$ pollen donor.

* Mean number of flowers produced per inflorescence within two months, counted from the scars of the floral pedicel in the inflorescence. 
seemed to play an important role in the reproductive biology of this species. Because of its physical proximity to the stigma, the anther crest is covered by stigmatic fluid. The data indicated that this structure helps to capture pollen grains, functioning as a stigmatic extension that must touch the pollinator's body at the time of the visit. Pollen grains that adhered to the anther crest reached the pistil because there was an increase in seed production when pollen was deposited on the structure, evidencing participation in the pollination process. In addition, the crest protects against the viscous secretion (stigmatic fluid) produced and stored at the apex of the stigma. In Costus (Zingiberales-Costaceae), this structure has the same function in pollination (Araújo and Oliveira, 2007).

In Roscoea debilis (Zingiberaceae), the stigmatic fluid forms a large globule and seeps into nearby pollen grains, inducing pollen germination and pollen tube elongation into the style. This process ensures reproduction when pollinators are limited (Fan and Li, 2012), which was not observed in the present study.

Similar to other Zingiberaceae species (Sakai et al., 1999), A. purpurata maintains the characteristics of insect-pollinated flowers, namely white, zygomorphic flowers with a landing platform and nectar rewards.

\section{CONCLUSION}

During the anthesis period, the anther's stigma and crest had receptivity, indicating that both structures were covered by stigmatic fluid. The A. purpurata flowers did not have stylet movement (flexistyly).

The cultivars had fruiting with the cross-pollination. Low fructification occurred with the natural pollination, and there was no fructification with the spontaneous self-pollination, manual self-pollination or geitonogamy.

Outcrossing in A. purpurata facilitates new natural hybrids for the ornamental plant market.

\section{ACKNOWLEDGMENTS}

This research was supported by a grant from the Fundação de Amparo à Pesquisa do Estado de Mato Grosso (FAPEMAT, process $159855 / 2014$ ) and the
Council of Technological and Scientific Development (CNPq), process 306183/2018) and was financed in part by the Coordenação de Aperfeiçoamento de Pessoal de Nivel Superior - Brasil (CAPES). The authors thank D.A. Costa, E. Aranda, and R.J. Silva for technical support and all members of the botanical laboratory.

Conflict of interests: This manuscript was prepared and reviewed with the participation of all authors, who declare that there was no conflict of interest posing a risk to the validity of the results reported.

\section{BIBLIOGRAPHIC REFERENCES}

Althaus-Ottmann, M.M., M.J.R. Cruz, and N. Fonte. 2011. Diversidade e uso das plantas cultivadas nos quintais do Bairro Fanny, Curitiba, PR, Brasil. Rev. Bras. Bioci. 9(1), 39-49. Doi: 10.7213/cienciaanimal.v9i1.11114

Araújo, F.P. and P.E. Oliveira. 2007. Biologia floral de Costus spiralis (Jacq.) Roscoe (Costaceae) e mecanismos para evitar a autopolinização. Rev. Bras. Bot. 30(1), 61-70. Doi: 10.1590/S0100-84042007000100007

Baskorowati, L.M.W., J.C. Moncur, P.J. Doran, and P.J. Kkanowski. 2010. Reproductive biology of Melaleuca alternifolia (Myrtaceae). Aust. J. Bot. 58(5), 373-383. Doi: 10.1071/BT10035

BFG, The Brazil Flora Group. 2015.Growing knowledge: an overview of seed plant diversity in Brazil. Rodriguésia 66(4), 1085-1113. Doi: 10.1590/2175-7860201566411

Box, M. and P.J. Rudall. 2006. Floral structure and ontogeny in Globba (Zingiberaceae). Plant Syst. Evol. 258, 107122. Doi: 10.1007/s00606-005-0395-4

Cardoso, J.C.F., M.L. Viana, R. Matias, M.T. Furtado, A.P.S. Caetano, H. Consolaro, and V.L.G. Brito. 2018. Towards a unified terminology for angiosperm reproductive systems. Acta Bot. Bras. 32(3), 329-348. Doi: 10.1590/0102-33062018abb0124

Dallacort, R., J.A. Martins, M.H. Inoue, P.S.L. Freitas, and A.J. Coletti. 2011. Distribuição das chuvas no município de Tangará da Serra, médio norte do Estado de Mato Grosso, Brasil. Acta Sci-Agron. 33(2), 193-200. Doi: 10.4025/actasciagron.v33i2.5838

Diggle, P.K. 1997. Extreme preformation in alpine Polygonum viviparum: an architectural and developmental analysis. Am. J. Bot. 84(2), 154-169. Doi: 10.2307/2446077

Embrapa, Empresa Brasileira de Pesquisa Agropecuária. 2018. Brazilian soil classification system. $5^{\text {th }}$ ed. Brasilia, DF.

Endress, P.K. 1994. Diversity and evolutionary biology of tropical flowers. Cambridge University Press, Cambridge, UK. 
Fan, Y.L. and Q.J. Li. 2012. Stigmatic fluid aids selfing in Roscoea debilis (Zingiberaceae): a new delayed selfing mechanism. Ann. Bot. 110(5), 969-975. Doi: 10.1093/ aob/mcs169

Fan, Y.L. and O.J. Li. 2016. Tail-like anther crest aids pollination by manipulating pollinator's behaviour in a wild ginger. Sci. Rep. 6, 22340. Doi: 10.1038/srep22340

Ferreira. D.F. 2000. Sisvar: a computer statistical analysis system. Cienc. Agrotec. 35(6), 1039-1042. Doi: 10.1590/S1413-70542011000600001

Hamidou, F.S., A.L. Witcher, C.T. Pounders, and J.M. Spiers. 2012. 'Ramata': A new dwarf variegated Hedychium (ornamental ginger) cultivar. HortScience 47(6), 803805. Doi: 10.21273/HORTSCI.47.6.803

JBRJ, Jardim Botânico do Rio de Janeiro. 2020. Flora do Brasil 2020. In: http://floradobrasil.jbrj.gov.br/reflora/floradobrasil/FB110701; consulted: February, 2020.

Kearns, C.A. and D.W. Inouye. 1993. Techniques for pollination biologists. University Press of Colorado, Niwot.

Kirchoff, B.K. 1988. Inflorescence and flower development in Costus scaber (Costaceae). Can. J. Bot. 62(2), 339345. Doi: 10.1139/b88-054

Kress, W.J. 1990. The phylogeny and classification of the Zingiberales. Ann. Missouri Bot. Gard. 77(4), 698-721. Doi: $10.2307 / 2399669$

Kress, W.J., L.M. Prince, W.J. Hahn, and E.A. Zimmer. 2001. Unraveling the evolutionary radiation of the families of the Zingiberales using morphological and molecular evidence. Syst. Biol. 50(6), 926-944. Doi: 10.1080/106351501753462885

Krieck, C., T. Finatto, T.S. Muller, M.P. Guerra, and A.I. Orth. 2008. Biologia reprodutiva de Alpinia zerumbet (Pers.) B.L. Burtt \& R.M. Sm. (Zingiberaceae) em Florianópolis, Santa Catarina. Rev. Bras. Pl. Med. 2(3), 103-110.

Li, Q.J., W.J. Kress, Z.F. Xu, Y.M. Xia, L. Zhang, X.B. Deng, and J.Y. Gao. 2002. Mating system and stigmatic behaviour during flowering of Alpinia kwangsiensis (Zingiberaceae). Plant Syst. Evol. 232, 123-132. Doi: $10.1007 / \mathrm{s} 006060200031$

Li, Q.J., Z.F. Xu, W.J. Kress, Y.M. Xia, L. Zhang, X.B. Deng, J.Y. Gao, and Z.L. Bai. 2001. Pollination: flexible style that encourages outcrossing. Nature 410, 432-432. Doi: $10.1038 / 35068635$

Luc-Cayol, F. and L.X. Fereol. 1997. Alpingera martinica (Zingiberaceae): an intergeneneric hybrid between Alpinia purpurata and Etlingera elatior. HortScience 32(5), 914 915. Doi: 10.21273/HORTSCI.32.5.914

Matlaga, D.P. and C. Horvitz. 2009. Large size and high light do not lower the cost of reproduction for the neotropical herb Goeppertia marantifolia. Am. J. Bot. 102(3), 350-357. Doi: 10.3732/ajb.1400363

Sakai, S., M. Kato, and T. Inoue. 1999. Three pollination guilds and variation in floral characteristics of Bornean gingers (Zingiberaceae and Costaceae). Am. J. Bot. 86(5), 646-658. Doi: 10.2307/2656573

Smith, R.M. 1990. Alpinia (Zingiberaceae): a proposed new infrageneric classification. Edinb. J. Bot. 47(1), 1-75. Doi: $10.1017 /$ S0960428600003140

Stevenson, D.W.M. and J.W. Stevenson. 2004. Costaceae (Costus Family). pp. 429-431. In: Smith, N., S.A. Mori, A. Henderson, D.W.M. Stevenson, and S.V. Heald (ed.). Flowering plants of the neotropics. Princeton University Press, Princeton, NJ.

Takano, A., J. Gisil, and J.M. Suleiman. 2013. Floral size variation causes differentiation of pollinators and genetic parameters in Alpinia nieuwenhuizii, a flexistylous ginger (Zingiberaceae). Plant Syst. Evol. 99, 865-871. Doi: $10.1007 / s 00606-013-0768-z$

WFO, World Flora Online. 2019. In: http://www.worldfloraonline.org; consulted: November, 2019.

Zhang, L., Q.J. Li, X.B. Deng, P.Y. Ren, and J.Y. Gao. 2003. Reproductive biology of Alpinia blepharocalyx (Zingiberaceae): another example of flexistyly. Plant Syst. Evol. 241, 67-76. Doi: 10.1007/s00606-003-0021-2 